\title{
Effect of Thalidomide on Brain Oxygenation
}

\author{
A. V. Beran ${ }^{[40]}$, J. Strauss, D. R. Sperling, A. G. Norton, V. P. Garwood, and J. Yamazaki \\ Department of Pediatrics, University of California, Irvine, College of Medicine, Irvine, and Childrens Hospital \\ of Los Angeles, University of Southern California School of Medicine, Los Angeles, California, USA
}

\begin{abstract}
Extract
This study was undertaken to evaluate the effect of thalidomide on oxygenation of maternal and fetal brain tissue. Oxygen availability $\left(\mathrm{O}_{2} \mathrm{a}\right)$ was determined polarographically using acutely and chronically implanted $\mathrm{Pt}$ and $\mathrm{AgCl}$ electrodes. Partial pressure of oxygen $\left(\mathrm{pO}_{2}\right)$ was measured polarographically in vitro from blood samples, and blood flow was determined in vivo by the hydrogen diffusion rate method. Thalidomide increased concentrations of $\mathrm{O}_{2}$ a in the brain of adult guinea pigs and fetuses by an average of 33 and $200 \%$, respectively. Simultaneously, jugular venous blood $\mathrm{pO}_{2}$ was increased, and arterial-venous (A-V) difference of $\mathrm{O}_{2}$ content, blood flow, and $\mathrm{O}_{2}$ consumption were decreased. Arterial blood $\mathrm{pO}_{2}, \mathrm{pH}$ and hemoglobin levels, body temperature, heart rate, and blood pressure were not affected by thalidomide. Niacinamide or hydrocortisone administered 30 to $60 \mathrm{~min}$ before the injection of thalidomide either decreased or prevented the thalidomide-induced response.
\end{abstract}

\section{Speculation}

It is postulated that thalidomide (or its metabolites) decreases cellular oxygen consumption by interfering with intermediary energy metabolism, and that this in turn could lead to developmental anomalies of the organism.

\section{Introduction}

The tragic story of thalidomide and its association with birth defects is now well known [14, 16, 18, 20, 27]. Although clinical use has been discontinued, thalidomide is a useful experimental tool in biological research for the study and modification of developmental $[3,6,7,17,19]$ and basic metabolic processes [9]. In the present study, evaluation of oxygen availability $\left(\mathrm{O}_{2} \mathrm{a}\right)$ in tissue, blood flow, and oxygen consumption have been used to determine the effect of thalidomide on such basic processes.

\section{Methods and Materials}

\section{Recording Techniques and Calculations}

Oxygen availability $\left(\mathrm{O}_{2} \mathrm{a}\right)$ in tissues was measured polarographically using a siliclad-coated [31] platinum-
$(\mathrm{Pt})$ cathode and an $\mathrm{Ag}-\mathrm{AgCl}$ reference anode. This technique depends upon the fact that molecular $\mathrm{O}_{2}$ is reduced at the $\mathrm{Pt}$ electrode by addition of two electrons (e-), developing a current that is directly proportional to the amount of oxygen reduced $[5,21$, 22]. In the present experiments the current was amplified [32] and recorded on a chart recorder [33].

Blood flow as measured by the hydrogen diffusion method, using platinum covered with platinic chloride as the active electrode and $\mathrm{Ag}-\mathrm{AgCl}$ as the reference electrode. This electrode system generates a negative voltage that is directly proportional to the number of $\mathrm{H}_{2}$ molecules present at the tip of the active electrode. When an animal breathes a gas mixture containing $\mathbf{H}_{2}$, the potential difference $(\Delta \mathrm{V})$ reaches a maximum when equilibrium is established between the $\mathrm{H}_{2}$ concentration around the active electrode and that in arterial blood. The linear slope time (LS), which is inversely 
proportional to the $\mathrm{H}_{2}$ diffusion rate, was taken as the index of tissue blood flow. The $\mathrm{H}_{2}$ was introduced in an inspired gas mixture composed of $5 \% \mathrm{H}_{2}, 20 \%$ $\mathrm{O}_{2}$, and $75 \% \mathrm{~N}_{2}[2,4,8,23,25]$.

The content and consumption of $\mathrm{O}_{2}$ were calculated from partial pressure of oxygen $\left(\mathrm{pO}_{2}\right)$ and hemoglobin data, using a rabbit blood $\mathrm{O}_{2}$ dissociation curve $[1,11$, 13], as follows:

1) The $\mathrm{O}_{2}$ content is equal to the physically dissolved $\mathrm{O}_{2}$ plus the $\mathrm{O}_{2}$ chemically combined in oxyhemoglobin.

$$
\mathrm{C}_{\mathrm{O}_{2_{\mathrm{T}}}}=\mathrm{C}_{\mathrm{O}_{2_{\mathrm{d}}}}+\mathrm{C}_{\mathrm{O}_{2_{\mathrm{Hb}}}}
$$

a. Physically dissolved $\mathrm{O}_{2}\left(\mathrm{C}_{\mathrm{O}_{\mathrm{d}}}\right)$ was calculated by the following formula: $\mathrm{C}_{\mathrm{O}_{2 \mathrm{~d}}}=\mathrm{pO}_{2}(100 \cdot \mathrm{S} / 760)$ where $\mathrm{S}$ is the Bunsen solubility coefficient for $\mathrm{O}_{2}$ in plasma at $37^{\circ}$ with dimensions $\mathrm{ml} / \mathrm{ml} / \mathrm{atm}$ and a value of 0.02356 .

b. Chemically combined $\mathrm{O}_{2}\left(\mathrm{C}_{\mathrm{O}_{2 \mathrm{gb}}}\right)$ was expressed using the following formula: $\mathrm{C}_{\mathrm{O}_{2 \mathrm{Hb}}}=\mathrm{S}_{\mathrm{O}_{2}} \times \mathrm{O}_{2}$ cap. where $\mathrm{O}_{2}$ cap. is oxygen capacity $(\mathrm{gHb} \times 1.34$ $\mathrm{ml} \mathrm{O}_{2}$ at $100 \%$ saturation), and $\mathrm{S}_{\mathrm{O}_{2}}$ is oxygen saturation, derived from the rabbit blood $\mathrm{O}_{2}$ dissociation curve using both $\mathrm{pO}_{2}$ and $\mathrm{pH}$ values.

2) Coefficient of $\mathrm{O}_{2}$ consumption (10) was calculated by the following formula:

$$
\mathrm{C}_{\dot{\mathrm{v}}_{\mathrm{O}_{2}}}=\frac{\mathrm{C}_{\mathrm{aO}_{2}}-\mathrm{C}_{\mathrm{jv}_{\mathrm{O}_{2}}}}{\mathrm{C}_{\mathrm{a}_{\mathrm{O}_{2}}}} \times \mathrm{F}
$$

$\mathrm{C}_{\mathrm{V}_{2} \mathrm{O}}$ : Coefficient of $\mathrm{O}_{2}$ consumption

$\mathrm{C}_{\mathrm{a}_{2}}$ : Common carotid or femoral artery $\mathrm{O}_{2}$ content (vol \%)

$\mathrm{C}_{\mathrm{jv}_{2}}:$ Jugular vein $\mathrm{O}_{2}$ content ( $\mathrm{vol} \%$ )

F: Blood flow

Arterial blood $\mathrm{pO}_{2}$ and $\mathrm{pH}$, rectal temperature, arterial blood pressure, heart rate, and blood hemoglobin levels were measured by conventional methods.

\section{Electrodes}

For recording $\mathrm{O}_{2}$ a of brain and bone marrow tissue in the adult, the active electrode $(75-\mu \mathrm{Pt}$ silicladcoated wire) was $7 \mathrm{~mm}$ long and insulated with epoxy resin except for $1 \mathrm{~mm}$ at the tip; the reference electrode (500- $\mu \mathrm{Ag}-\mathrm{AgCl}$ wire) was $2 \mathrm{~mm}$ long and uninsulated. Electrodes used in the fetus were thin, flexible wires coated with epoxy resin; a ball of resin was formed at the end of each electrode, and the insulation was scraped off a $1-\mathrm{mm}$ section $4 \mathrm{~mm}$ from the end of the wire. The active cathode was $75-\mu$ siliclad-coated $\mathrm{Pt}$ wire; the reference anode was $175-\mu \mathrm{Ag}$ wire with a bare section $2 \mathrm{~mm}$ long, chlorided electrolytically in $0.1 \mathrm{~N}$ HCI. For recording blood flow in brain tissue, the electrodes were similarly constructed, except the active $\mathrm{Pt}$ electrode was coated electrolytically with platinum black in a $3 \%$ solution of platinum chloride.

\section{Surgical Techniques}

A total of 106 guinea pigs (66 nonpregnant adults, 14 pregnant females, and 26 fetuses) and 12 adult rabbits were used in these studies.

Holes were drilled in the skulls of adult animals, and electrodes were inserted into the parietal brain cortex and the parietal bone marrow. The electrodes were soldered to external connectors which then were fixed to the skull with dental cement.

In the fetus, the abdomen of the mother was opened, the uterus was exposed, and the head of the fetus was located by palpation. A no. 25 syringe needle was passed through the parietal region of the fetal head. Electrodes were threaded through the needle until the end with the ball of resin rested snugly against the fetal skull. The needle was removed and the electrode was left with its bare portion inside the brain. After the abdomen was closed, up to $6 \mathrm{hr}$ was allowed for recovery from anesthesia and surgical trauma; fetal records were obtained for 1-2 days thereafter.

During the experiments, cannulae were inserted to draw blood samples from the femoral or ear lobe arteries and from the jugular vein. Three blood samples were obtained in the control period; thalidomide [35] was then injected; samples were repeatedly drawn as soon as the increase in brain $\mathrm{O}_{2}$ a was recorded, when brain $\mathrm{O}_{2}$ a neared a maximum, and at 1- to 2-hr intervals during recovery.

\section{Drugs}

A suspension of $100 \mathrm{mg}$ thalidomide and $100 \mathrm{mg}$ methylcellulose [36] in $2 \mathrm{ml}$ saline was used in these experiments. Niacinamide [37] (150-200 $\mathrm{mg} / \mathrm{kg})$ or hydrocortisone [38] $(200 \mathrm{mg} / \mathrm{kg})$ was injected $30-60 \mathrm{~min}$ before administration of a standard $100 \mathrm{mg} / \mathrm{kg}$ dose of thalidomide. All injections were given intraperitoneally.

\section{Results}

Studies in vitro indicated that $\mathrm{O}_{2^{-}}$and $\mathrm{H}_{2}$-sensitive electrodes were unaltered by thalidomide.

Effects of Thalidomide on $\mathrm{O}_{2}$ a Levels in Brain and Bone Marrow

The typical response of brain tissue was a gradual increase in $\mathrm{O}_{2}$ a beginning $20 \mathrm{~min}$ after injection, reach- 


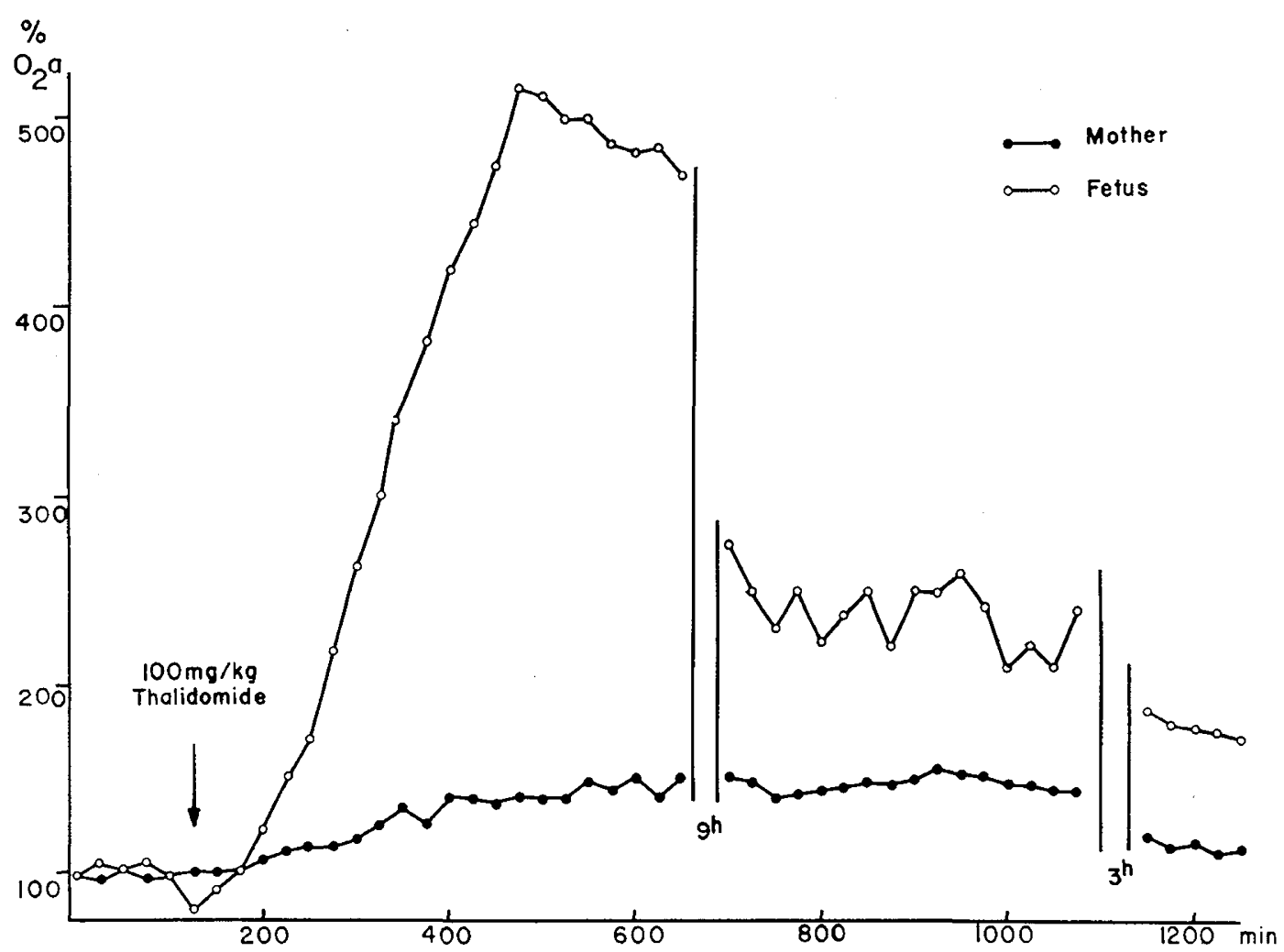

Fig. 1. Effect of thalidomide on oxygen availability in brain of a maternal and a fetal guinea pig.

ing a maximum $2 \mathrm{hr}$ after injection, and returning to normal values within $24 \mathrm{hr}$ (Fig. 1). Though there was no difference between the response of pregnant and nonpregnant animals, the response in fetuses was greater in amplitude and duration than in adult animals (Table $\mathrm{I}$ ).

Thalidomide administration also induced the appearance of large amplitude fluctuations of the $\mathrm{O}_{2} \mathrm{a}$ base line at the rate of $2-3 / \mathrm{min}$. Smaller waves or "slow waves" $[5,12,21,29]$ at the rate of $14 / \mathrm{min}$ were superimposed on the base-line fluctuations. The increase in large base-line fluctuations appeared about $2 \mathrm{hr}$ after injection of thalidomide with the increase in brain $\mathrm{O}_{2}$ a (Fig. 2, C through E); these fluctuations were similar to those observed in fetuses during uterine contractions [21, 22], and in animals exposed to $\mathrm{O}_{2}$ pressures of 45 pounds per square inch gauge (psig).

The effect of thalidomide on $\mathrm{O}_{2} \mathrm{a}$ in bone marrow (used as an indication of changes in tissues other than brain) of eight adult rabbits was greater than that observed in brain tissue; the increase averaged $50 \%$ $( \pm 30 \%)$. The $\mathrm{O}_{2} \mathrm{a}$ in bone marrow remained elevated when daily injections of thalidomide were administered and returned to normal within $24 \mathrm{hr}$ after the last injection.

\section{Blockage of Thalidomide Effect by Niacinamide and Hydrocortisone}

Niacinamide (150-200 $\mathrm{mg} / \mathrm{kg}$ ) was injected into seven adult, seven fetal, and five pregnant guinea pigs $30-60 \mathrm{~min}$ before administration of a standard $100 \mathrm{mg} /$ $\mathrm{kg}$ dose of thalidomide. The effect of niacinamide on $\mathrm{O}_{2}$ a levels in brain and in cerebral blood flow was varied and insignificant. In contrast to the marked increase of $\mathrm{O}_{2}$ a normally following administration of thalidomide (Fig. 1), there was no change in the $\mathrm{O}_{2}$ a level in five adult, five fetal, and four pregnant female guinea pigs receiving pretreatment (Fig. 3). In the

Table I. Effect of thalidomide on oxygen availability in brain of adult, pregnant, and fetal guinea pigs

\begin{tabular}{lccc}
\hline & $\begin{array}{c}\text { Adult } \\
\text { average }\end{array}$ & $\begin{array}{c}\text { Maternal } \\
\text { average }\end{array}$ & $\begin{array}{c}\text { Fetal } \\
\text { average }\end{array}$ \\
\hline $\begin{array}{l}\text { No. of exp. } \\
\text { Onset of response, } \\
\quad \text { min }\end{array}$ & 28 & 9 & 14 \\
$\begin{array}{l}\text { Maximum change, } \\
\quad \text { min }\end{array}$ & $145 \pm 70$ & $185 \pm 80$ & $210 \pm 120$ \\
$\begin{array}{l}\mathrm{O}_{2} \text { a increase, } \% \\
\text { Duration, hr }\end{array}$ & $33 \pm 13$ & $32 \pm 15$ & $200 \pm 130$ \\
& $13 \pm 5$ & $13 \pm 6$ & $18 \pm 8$ \\
\hline
\end{tabular}

${ }^{1} \pm \mathrm{SD}$. 


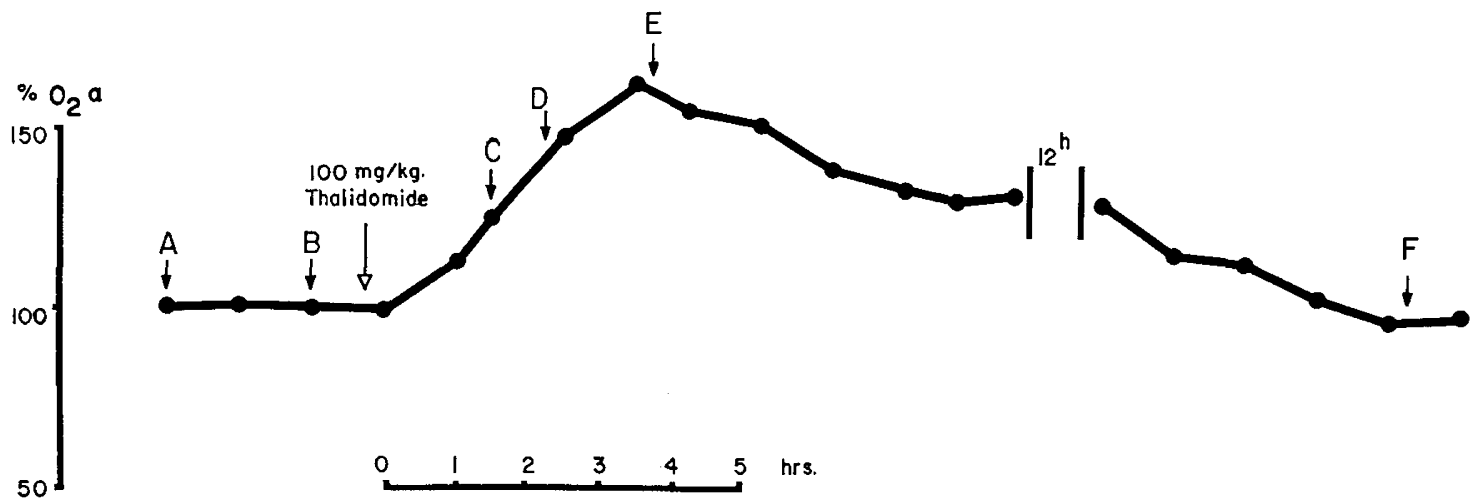

A

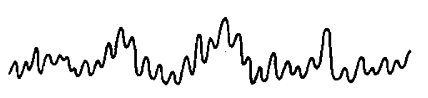

B.

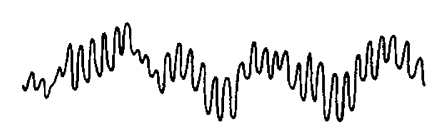

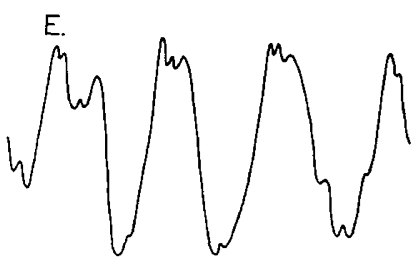

C.

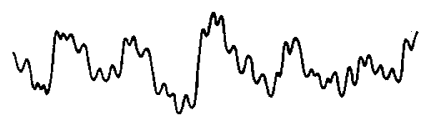

F.

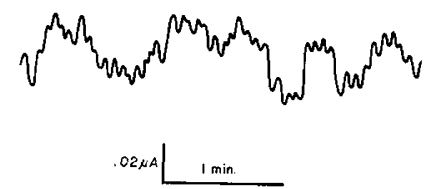

Fig. 2. Effect of thalidomide on oxygen availability in brain of an adult rabbit. Note that as $\mathrm{O}_{2}$ a increases, base-line fluctuations appear. Amplitude of the fluctuation increases to reach a maximum at the height of the $\mathrm{O}_{2}$ a level and disappears as the $\mathrm{O}_{2}$ a level returns to normal. $A, B$ : control. $C, D, E$ : during effect of thalidomide. $F: \mathrm{O}_{2}$ a back to normal.

remaining five animals, the thalidomide-induced $\mathrm{O}_{2} \mathrm{a}$ increase occurred, but was $50 \%$ less than the increase observed in animals without pretreatment. No differences were observed among the adult, fetal, or pregnant female animals. Pretreatment of six adult nonpregnant guinea pigs with hydrocortisone $(200 \mathrm{mg} / \mathrm{kg})$ produced a blockage of the thalidomide effect similar to that produced by pretreatment with nicotinamide; hydrocortisone alone decreased $\mathrm{O}_{2} \mathrm{a}$ in brain tissue by $8 \%( \pm 3 \%)$. The large base-line fluctuations, observed after administration of thalidomide, were not blocked by pretreatment with either nicotinamide or hydrocortisone.

\section{Effect of Thalidomide on Cerebral Blood Flow}

Thalidomide $(100 \mathrm{mg} / \mathrm{kg})$ was injected into five pregnant and five adult nonpregnant guinea pigs. In all animals, LS increased by $40 \%( \pm 8 \%)$ and $\Delta \mathrm{V}$ decreased by $25 \%( \pm 8 \%)$. Both of these indices sug- gest a decrease in cerebral blood flow following administration of thalidomide (Fig. 4).

Effect of Thalidomide on Blood $\mathrm{pO}_{2}, \mathrm{O}_{2}$ Content, and $\mathrm{O}_{2}$ Consumption

Arterial (A) and venous (V) blood samples were analyzed for $\mathrm{pO}_{2}$, and their differences were calculated. Changes in $\mathrm{A}-\mathrm{V} \mathrm{pO}_{2}$ differences in all six rabbits were similar to changes in brain $\mathrm{O}_{2}$ a (Fig. 5). Differences in $\mathrm{A}-\mathrm{V} \mathrm{pO}_{2}$ decreased from an average of $44 \pm$ $10 \mathrm{~mm} \mathrm{Hg}$ during the control period to an average of $35 \pm 10 \mathrm{~mm} \mathrm{Hg}$ after administration of thalidomide. No change was observed in arterial blood $\mathrm{pO}_{2}$, but venous blood $\mathrm{pO}_{2}$ increased. The maximum decrease in $\mathrm{A}-\mathrm{V} \mathrm{pO}_{2}$ difference was $20 \pm 10 \%$.

The average $A-V$ difference of $\mathrm{O}_{2}$ content was 4.98 $\pm 0.35 \mathrm{ml} / 100 \mathrm{ml}$. After thalidomide administration, the $\mathrm{A}-\mathrm{V}$ difference of $\mathrm{O}_{2}$ content decreased to an average of $2.89 \pm 0.77 \mathrm{ml} / 100 \mathrm{ml}$, or by $42 \pm 12 \%$.

The average coefficient of $\mathrm{O}_{2}$ consumption was 


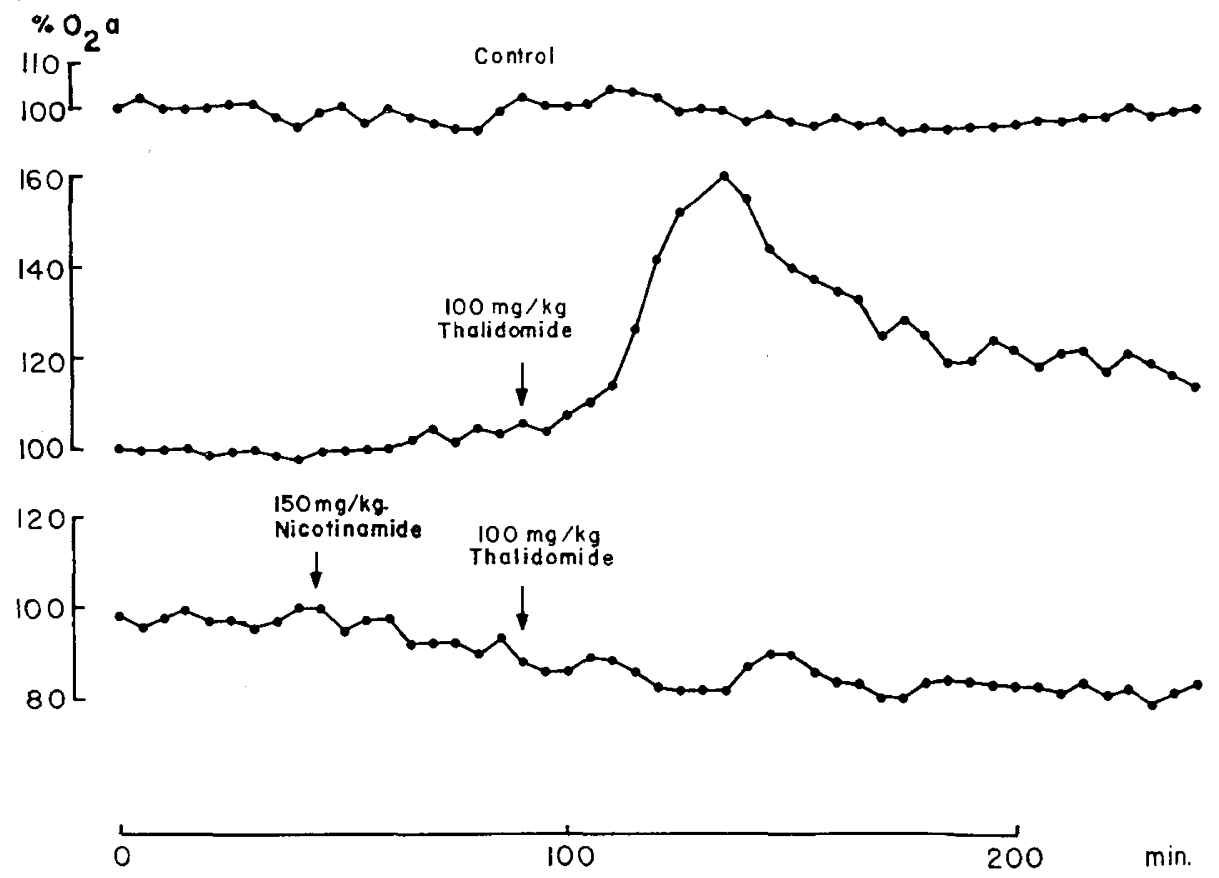

Fig. 3. Effect of thalidomide, alone and after administration of $150 \mathrm{mg} / \mathrm{kg}$ nicotinamide, on oxygen availability in brain of an adult guinea pig.

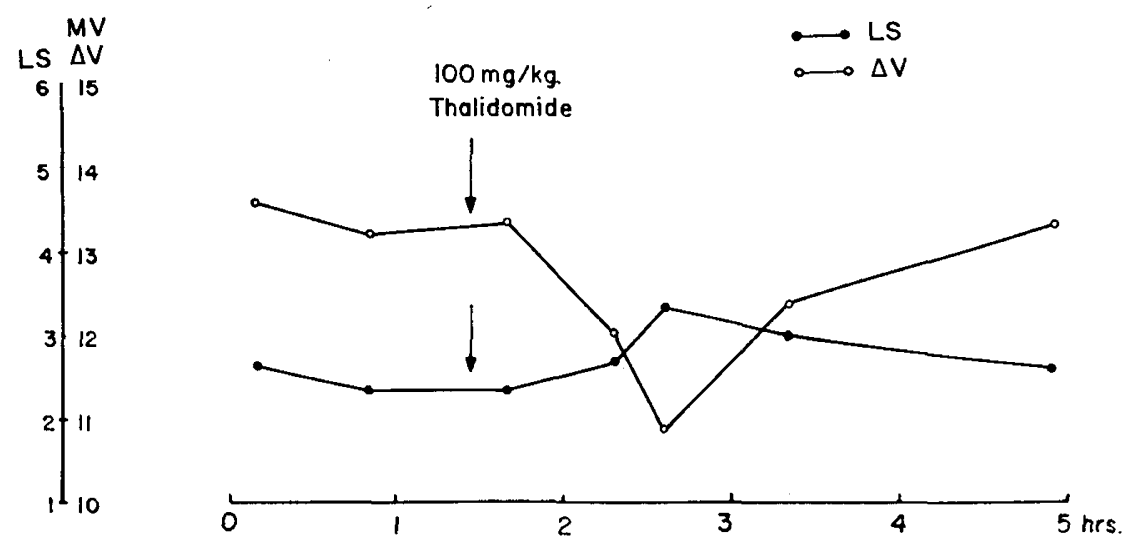

Fig. 4. Effect of thalidomide on cerebral blood flow of an adult guinea pig. LS: linear slope. $\Delta \mathrm{V}$ : potential difference.

23.2\%. After administration of thalidomide, it decreased by $62 \%$ to an average coefficient of $8.8 \%$.

Effect of Thalidomide on Body Temperature, Blood Pressure, and Heart Rate

No changes in body temperature, blood pressure, or heart rate were observed during or after the increase of mean brain $\mathrm{O}_{2}$ a produced by thalidomide.

\section{Discussion}

The changes in $\mathrm{O}_{2}$ a reported in the present study were reproduced under a variety of conditions. The effects observed in vivo cannot be attributed to electrochemical artifacts, since the in vitro experiments demonstrated that neither thalidomide nor the other drugs used had any direct effect on $\mathrm{O}_{2}$ current. Justification of the use of polarographic methods for measurement of tissue $\mathrm{O}_{2}[5,21,22,24,29]$ and the potentiometric $\mathrm{H}_{2}$ diffusion method for measurement of tissue blood flow $[2,4,8,23,25]$ has been previously established.

The increased $\mathrm{O}_{2}$ a observed in brain and bone marrow following administration of thalidomide could be caused by either an increase in the supply of $\mathrm{O}_{2}$ or a decrease in the consumption of $\mathrm{O}_{2}$. The former has 


\section{$\longrightarrow \mathrm{O}_{2} \mathrm{a}$ \\ $\propto \mathrm{pO}_{2}$}

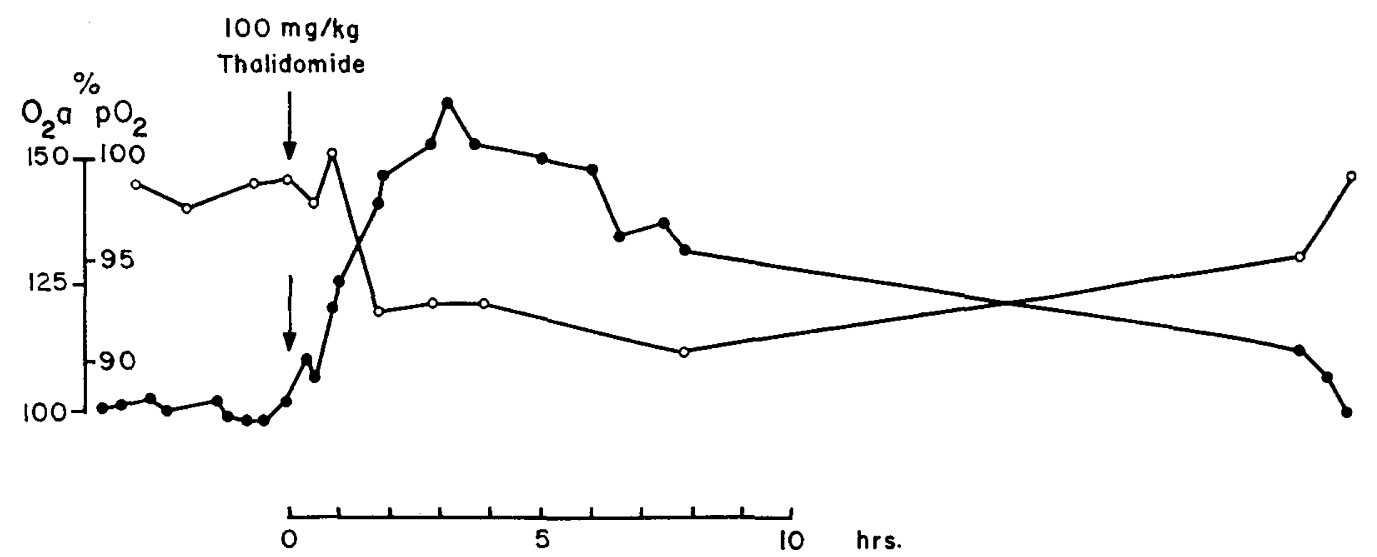

Fig. 5. Effect of thalidomide on oxygen availability in brain and on $\mathrm{A}-\mathrm{V}$ blood $\mathrm{pO}_{2}$ of an adult rabbit.

been rejected, since no increase in arterial $\mathrm{pO}_{2}$ was noted and, furthermore, a decreased blood flow through the brain was recorded. The latter mechanism, decreased cerebral consumption of $\mathrm{O}_{2}$, is supported by the results of measurement and calculation $(62 \%$ decrease in $\mathrm{O}_{2}$ consumption). Venous blood returning from the brain showed an increase in $\mathrm{C}_{\mathrm{O}_{2}}$ that paralleled an increase in $\mathrm{O}_{2}$ a.

The finding that nicotinamide blocks the thalidomide-induced increase of $\mathrm{O}_{2}$ a adds further support to the above interpretation and also suggests a possible mechanism for the decreased $\mathrm{O}_{2}$ consumption. The role of nicotinic acid as a coenzyme in cellular respiration and intermediary energy metabolism is well established. Interference with these systems could be expected to decrease $\mathrm{O}_{2}$ consumption, producing an accumulation of $\mathrm{O}_{2}$ at the tissue level. It has been reported that thalidomide interferes with metabolism in protozoa and that this interference is related to nicotinic acid [9].

Thalidomide induced two types of changes in $\mathrm{O}_{2} \mathrm{a}$ : increase in the $\mathrm{O}_{2}$ a level and increase in base-line fluctuations. The overall increase of $\mathrm{O}_{2} \mathrm{a}$ was completely or partially blocked by niacinamide and hydrocortisone, but the fluctuations were essentially unaffected.

The increase in base-line fluctuations could be attributed to the alternate opening and closing of the precapillary sphincter as a response of autoregulatory mechanisms to the increase in $\mathrm{O}_{2}$ a [12]. The decrease in tissue blood flow could be explained as a response of autoregulatory mechanisms to the increased $\mathrm{O}_{2}$ a, as postulated for brain and muscle $[12,15,26,30]$.

In conclusion, the interpretation most consistent with the present findings is that thalidomide interferes with intermediary metabolism; the resulting decrease in $\mathrm{O}_{2}$ consumption results in an increase in tissue $\mathrm{O}_{2}$ levels, which in turn triggers autoregulatory mechanisms by decreasing the local tissue blood flow. This effect was not limited to brain tissue and was greater in the fetus than in the adult. It seems reasonable that the suggested interference with intermediary metabolism could lead to developmental anomalies.

\section{Summary}

The effect of thalidomide on brain oxygen availability $\left(\mathrm{O}_{2} \mathrm{a}\right)$, blood flow, and oxygen consumption was studied in a series of normal adult, pregnant, and fetal guinea pigs. The $\mathrm{O}_{2}$ a was significantly increased in all experiments following administration of thalidomide. This effect was decreased or prevented by the prior administration of niacinamide or hydrocortisone. The $\mathrm{O}_{2}$ consumption in brain and $\mathrm{A}-\mathrm{V} \mathrm{O}_{2}$ content difference were decreased significantly, suggesting that the drug interfered with oxygen consumption in both fetal and adult brains.

\section{References and Notes}

1. Altman, P. L., Grbson, J. F., JR., And Wong, C. C.: Handbook of Respiration, p. 55 (Saunders, Philadelphia, 1958).

2. Aukland, K. B., Bower, B. F., and Berliner, R. W.: Meas- 
urement of local blood flow with hydrogen gas. Circ. Res., 14: 164 (1964).

3. Boylen, J. B., Horne, H. H., AND Johnson, W. J.: Teratogenic effects of thalidomide and related substances. Lancet, $i: 552$ (1963).

4. Clark, L. G., JR., and Misrahy, G. A.: An electrochemical method to measure hydrogen gas in biological tissue (Abstract). Int. Physiol. Congr., 20th, Brussels, No. 177 (1957).

5. Clark, L. G., Jr., Misrahy, G., and Fox, R. P.: Chronically implanted polarographic electrodes. J. Appl. Physiol., 13: 85 (1958).

6. Cook, M. J., AND MOore, D. F.: The effect of thalidomide on the development of rat fetus. Brit. J. Exp. Pathol., 48: 150 (1967).

7. DeBock, C. A., and Peters, A.: Effect of thalidomide on the development of the chick embryo. Nature, 199: 1204 (1963).

8. Fueschi, C., Bozzao, L., Agnoli, A., Nardini, M., and BartoLINI, A.: The hydrogen method of measuring local blood flow in subcortical structures of the brain: Including a comparative study with the $14 \mathrm{C}$ antipyrine method. Exp. Brain Res., 7: 111 (1969).

9. Frank, O., Baker, H., Ziffer, H., Aaronson, S., Hutner, S. H., AND CEEvY, C. M.: Metabolic deficiencies in protozoa induced by Thalidomide. Science, 139: 110 (1963).

10. Fulton, J. F.: A Textbook of Physiology, p. 800 (Saunders, Philadelphia, 1949).

11. George, W. C.: Comparative hematology and the function of leucocytes. Quart. Rev. Biol., 16: 426 (1941).

12. Guyton, A. C., Ross, J. M., Carrier, O., JR., and Waler, Y. R.: Evidence for tissue oxygen demand as the major factor causing autoregulation. Circ. Res., 15 (suppl. 1): 60 (1964).

13. JoRdon, H. E.: Comparative hematology. In: Handbook of Hematology, Vol 2, p. 703 (Paul B. Hoeber, New York, 1938).

14. Jung, H.: Clinical experience with a new sedative, Arzneimittel-forschung, 6: 430 (1956)

15. LAsSEN, A. N.: Autoregulation of cerebral blood flow. Circ. Res., 15 (suppl. 1): 201 (1964).

16. LENZ, W.: Thalidomide and congenital abnormalities. Lancet, $i: 45$ (1962).

17. Lucys, J. F.: Thalidomide: Effect upon pregnancy in the Rhesus monkey. Science, 139: 1295 (1963).

18. Lunz, W., Keller, H., ANd Muckter, H.: N-Phthalylglutamic acidimide. Arzneimittel-forschung, 6: 426 (1956).

19. LUTWAK-MANN, AND HAY, M. F.: Effect on the early embryo of the agents administered to the mother. Brit. Med. J., 1: 944 (1962).

20. Mellin, G., and Katzenstein, M.: The saga of thalidomide. New Engl. J. Med., 267: 1184, 1238 (1962).

21. Misrahy, G. A., Beran, A. V., and Hardwick, D. F.: Fetal and neonatal brain oxygen. Amer. J. Physiol., 203: 160 (1962).

22. Misrahy, G. A., Beran, A. V., Spradley, J. F., and Garwood, V. P.: Fetal brain oxygen. Amer. J. Physiol., 199: 959 (1960).

23. Misrahy, G. A., Beran, A. V., Sxrauss, J., and Garwood, V. P.: Diffusion of hydrogen to the fetal brain and neonatal brain and kidney. Exp. Neurol., 8: 361 (1963).

24. Misrahy, G. A., Hardwick, D. F., Brooks, C. J., Garwood, V. P., AND HALL, W. P.: Bone, bone marrow and brain oxygen. Amer. J. Physiol., 202: 226 (1962).

25. Neely, A. W., Turner, M. D., Hardy, D. J., and Godfrey, W. D.: The use of hydrogen electrode to measure tissue blood flow. J. Surg. Res., 5: 363 (1965).

26. RAPELA, E. G., AND GREEN, D. H.: Autoregulation of canine cerebral blood flow. Circ. Res., 15 (suppl. 1): 205 (1964).

27. Speirs, A. L.: Thalidomide and congenital abnormalities. Lancet, $i$ : 303 (1962).

28. Sperling, D. R., Nathaniel, D., Strauss, J., Beran, A. V., AND Misrahy, G.: Oxygen toxicity in newborn and adult mice. (Manuscript in preparation.)

29. Strauss, J., Beran, A. V., Brown, C. T., and Katurich, N.: Renal oxygenation under "normal" conditions. Amer. J Physiol., 215: 1482 (1968).

30. Strauss, J., Garwood, V. P., Beran, A. V., and Misrahy, G. A.: Variations in brain and blood oxygen during prolonged hypoxia. Clin. Res., 13: 117 (1965).

31. Clay-Adams, Inc., New York, N. Y.

32. HP8875A differential DC amplifier, Hewlett-Packard Company, Palo Alto, Calif.

33. Esterline-Angus AW, Esterline-Angus, Indianapolis, Ind.

34. Epoxylite Corporation, El Monte, Calif.

35. Kevadon, The Wm. S. Merrell Company, Cincinnati, Ohio.

36. Methocel, Dow Chemical Company, Midland, Mich.

37. E1, Lilly \& Company, Indianapolis, Ind.

38. Solu-Cortef, Upjohn Company, Kalamazoo, Mich.

39. Supported by National Institutes of Health Grants nos. HE 09351 and NB 03453.

40. Request for reprints should be addressed to: A. V. Beran, Department of Pediatrics, University of California, Irvine, College of Medicine, Irvine, Calif. (92664) USA.

41. Accepted for publication July $15,1970$. 